\title{
Reflecting on the Impact of Globalization on Albania: An Analyses throughout History
}

\author{
Marsida (Salihi) Tafilica \\ $P h D(C)$, Clemson University
}

\section{Doi: 10.2478/mjss-2018-0104}

\begin{abstract}
Drawing upon components from inventory models of globalization, this paper aims to contribute to the presenting influence of globalization in Albania region, using data from national and international sources. Like many other developing countries, Albania could not be conditioned by the existence of a process such as globalization, which found Albania as a post-communist country that in 90 s had just been confronted with the challenges of a fragile democracy. Being completely vulnerable to changes and pressures that the international community offered to them, this society has lost the selection ability. The purpose of this paper is to observe both the negative and the positive impacts of globalization on Albania. Furthermore, it attempts to suggest some recommendations among which are to assist in developing democratization process and improving the quality of life.
\end{abstract}

Keywords: globalization, Albania, quality of life, economic impact, social impact

\section{Geography and Demographics}

The Republic of Albania, its native name "Shqiperia" meaning "Land of Eagles", is a small country located on Southeastern Europe's Balkan Peninsula. The country has the Adriatic and Ionian coastlines and an interior crossed by the Albanian Alps. Albania is bordered by Kosovo to the northeast, Montenegro to the northeast, the Republic of Macedonia to the east, and Greece to the south and southeast. With a total area of 28,748 square kilometers, it is slightly smaller than Maryland. It has 362 kilometers of coastline facing the Adriatic and Ionian Sea but Albania's terrain is dominated mostly by mountains and hills. Taking into account its geographical position, Albania's natural resources include natural gas, chromite, iron ore, salt, arable land, and hydropower (CIA 2017).

The July 2016 population estimate of $3,038,594$ is decreasing at rate of $-0.04 \%(-1042$ people). The sex ratio of the total population was 0.88 male(s)/female which is lower than global sex ratio. Death rate is lower (6.7 deaths $/ 1,000$ population) than birth rate (13.1 births/1,000 population), as well as a negative migration rate of -3.3 migrants $/ 1,000$ population. The age structure consists of $0-14$ years: $18.37 \%, 15-64$ years: $70.05 \%$, and 65 years and over: $11.58 \%$, with a median age of 32.5 years. Ethnic and cultural affiliation of resident population is Albanian $82.6 \%$, Greek $0.9 \%$ and other or unspecified ethnicities $16.5 \%$ (including Vlach, Roma (Gypsy), Macedonian, Montenegrin, and Egyptian). The Greek and Macedonian minorities are mostly concentrated in the south of Albania while other minorities are concentrated in the north of the country. Regardless of all these minority groups, Albanian is the official language that $98.8 \%$ of the population speaks. The majority of population is Muslim (56.7\%), while for the most part, the rest of it is either Orthodox (6.8\%) or Catholic Christian (10\%) (CIA 2017). After the communist collapse in 1991, new religious communities and groups extended in Albania. These groupings belong to a large variety of religious communities, such as Protestant, Evangelical, New Apostolic, Baptist, Mormon and Bahai. Recently, communities of Jehovah's Witnesses are present. Also, Buddhism is another religious community that is receiving consent from a considerable part of the population. 


\section{World History}

For nearly four centuries, XV to XIX century, Albania has been part of the Ottoman Empire. Before the Ottoman rule, for seventeen centuries, the country has been under Roman, Byzantine, Bulgarian, Serbian, and Venetian occupation. Under the Ottoman Empire, Albanians became part of conversion to the Islamic religion. As Ferrari, Durham, and Sewell (2003) claimed "Historians attribute the conversion to many reasons: the desire to escape the heavy Ottoman tax burdens, non-assimilation with non-Muslim neighbors, and the geographical location of Albania" (p. 23).

For the first time in its history, Albania was declared an independent state on November 28, 1912. During WWII, the country was conquered by Italy in 1939 and occupied by Germany in 1943; while, after World War II, many states elected Marxist ideological model as a type of regime. Around the world there have been many type of systems including communist and fascist systems and Albania was one of the countries that entered its communist period in November 1944. For many years, Albania was Eastern Europe's most oppressive and authoritarian state. For about 50 years, she has been under a single party. In such conditions, the Communist Party of Albania became the only political actor in the country. During communist regime, the system declared the separation of state from the church, and came out with the destruction of the churches and the mosques. In 1967, Albania was declared as the first atheist state in the world. In 1991, international geopolitical circumstances overthrew the communist regime in Albania. The country joined the United Nations in 1955; in 2009, it became a NATO member; and since September 2000, Albania has been part of World Trade Organization.

\section{Government}

Albania is a parliamentary republic as a government type which means it is a democratic form of governance in which the party (or a coalition of parties) with the greatest representation in the parliament forms the government and its head becoming prime minister. The Albanian chief of state is the president, indirectly elected by the Assembly for a five-year term. The 140 members of the unicameral assembly, Kuvendi, are elected to four-year terms by proportional representation. According to the latest elections held on 25 June 2017, current party seats include: Socialist Party (74), Democratic Party (43), LSI (19), PDIU (3), and Social Democrats (1) (CIA 2017).

Political parties are a significant component of the advance of a democratic system. Electoral systems also play an important role in affecting democratic systems nowadays. These components provide if the system is either democratic or autocratic. With the collapse of the communist regime, new democratic political parties appeared in Albania. Currently, Albania has a multi-party system with two major political parties and some other third parties.

Some questions raised during this paper might be: Does Albania fulfill the standards to be part of a democratic system? Does it have a stable government? According to Freedom House (2016), Albania is in a transitional government or hybrid regime with a democracy score of 4.14 . The country has a lot to do particularly in the fight against corruption and organized crime. Below I am representing a table which shows the rating scores from 2007 to 2016 . The scores range from scale 1 to scale 7 , in which scale 1 shows the highest progressive level of democracy and 7 the lowest.

Table 1. Albania in Transit Category and Democracy Scores

\begin{tabular}{|l|c|c|c|c|c|c|c|c|c|c|}
\cline { 2 - 9 } \multicolumn{1}{c|}{} & $\mathbf{2 0 0 7}$ & $\mathbf{2 0 0 8}$ & $\mathbf{2 0 0 9}$ & $\mathbf{2 0 1 0}$ & $\mathbf{2 0 1 1}$ & $\mathbf{2 0 1 2}$ & $\mathbf{2 0 1 3}$ & $\mathbf{2 0 1 4}$ & $\mathbf{2 0 1 5}$ & $\mathbf{2 0 1 6}$ \\
\hline National Democratic Governance & 4.25 & 4.25 & 4.25 & 4.5 & 4.75 & 4.75 & 5 & 4.75 & 4.5 & 4.5 \\
\hline Electoral Process & 4 & 4 & 3.75 & 3.75 & 4 & 4.25 & 4.25 & 4 & 4 & 3.75 \\
\hline Civil Society & 3 & 3 & 3 & 3 & 3 & 3 & 3 & 3 & 3 & 3 \\
\hline Independent Media & 3.75 & 3.75 & 3.75 & 4 & 4 & 4 & 4 & 4 & 4 & 4.25 \\
\hline Local Democratic Governance & 2.75 & 2.75 & 2.75 & 3 & 3.25 & 3.25 & 3.5 & 3.5 & 3.5 & 3.5 \\
\hline Judicial Framework and Independence & 4 & 4 & 4.25 & 4.25 & 4.25 & 4.75 & 4.75 & 4.75 & 4.75 & 4.75 \\
\hline Corruption & 5 & 5 & 5 & 5 & 5 & 5 & 5.25 & 5.25 & 5.25 & 5.25 \\
\hline Democracy Score & 3.82 & 3.82 & 3.82 & 3.93 & 4.04 & 4.14 & 4.25 & 4.18 & 4.14 & 4.14 \\
\hline
\end{tabular}

Source: Freedom House (2016) 


\section{Descriptive Data - Economy}

Since transition period, Albania has an impressive history of economic growth. Economic growth, since 1990, is among the highest in all transition economies. This is why real incomes of Albania has recovered to pre-transition levels, although the country remains one of the poorest countries in Europe. Albania's economic performance has been reflected in the change from a closed, centrallyplanned state, in an open-market economy. "Albania managed to weather the first waves of the global financial crisis but, more recently, the negative effects of the crisis have caused a significant economic slowdown. Close trade, remittance, and banking sector ties with Greece and Italy make Albania vulnerable to spillover effects of debt crises and weak growth in the euro zone" (CIA 2017).

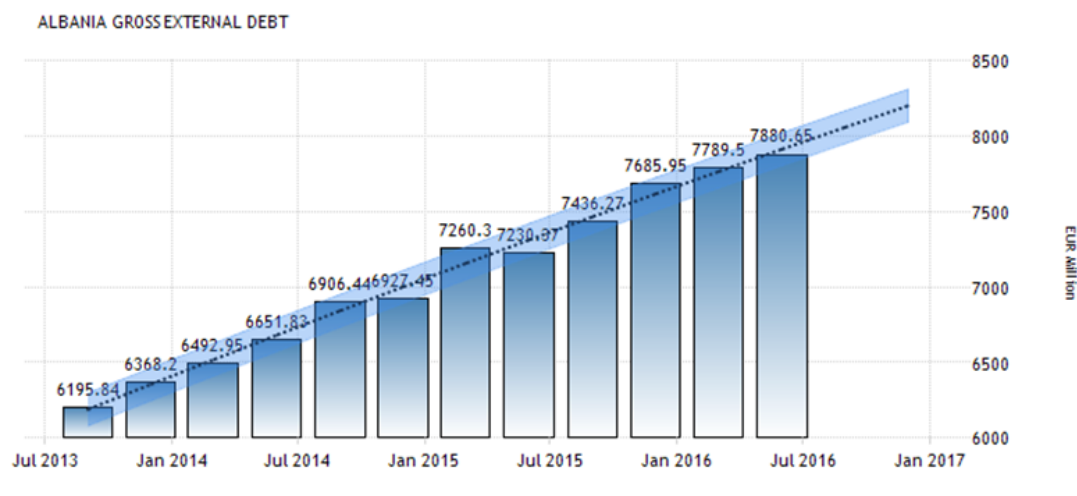

Source: Trading economics (2016)

In many countries the growth of public-debt ratio to GDP implies that there will be a risk of raising the tension on autonomous financing capacity. Even though earnings are a very strong instrument to prevent public debt (as percentage of GDP) from the blast, such a process in the long term will lead to higher tax rates above the accepted levels of society and, consequently, will lead either to bankruptcy or the need for a sudden change in institutional arrangements. Therefore, the major spending returns are of great importance to help the sustainability of the Albanian fiscal institutions. Tax and spending reforms may be needed to achieve the target level of debt in the long term, but also need to have economic growth over a sustained period of time. Achieving the desired results may not be as satisfactory if we rely only on tax administration. Beside their management, it should be made some changes in tax policies, including tax rate on incomes. During last year, it has seen a change in tax policies, but those amendments must be associated with a greater increase revenue. Otherwise, such a situation where increasing taxes and economic growth is not so great, it would have a great impact on the population and consequently on the entire economy. Besides scope to income tax, it is required to have a tight control on expenses and an increase on public sector salaries that are in line with inflation. These reforms will create fiscal space for governments to undertake major capital spending to ease infrastructure constraints, to support growth and maintain a share of the costs for social service delivery to the poor and helpless people.

Public debt is too high, fiscal financing needs are the highest in Eastern Europe, economic rebalancing is incomplete, including a large external deficit of the current account. Albania is facing a very big risk with such a high debt. In the medium term, the growth of public debt could hurt private businesses by reducing prospects for them to obtain credit and finance in this country. Also, the decrease of the possibility that the government to be funding of the projects would make a difference in the level of the revenue in Albania. Global crises have caused fiscal serious damage, which have left the world faces significant challenges. This shows that the Albanian government still has much work to do to change attitude to fiscal policy. The flow of foreign direct investment (FDI) is an important factor for economic growth, particularly in small and underdeveloped countries. 
They are a very important source of income, employment, technological development and modernization. FDI increased by a tremendous rate since the early 1980 s and the global market has become more competitive. Developing countries have become attractive investment destinations as investors offer a variety of created assets. FDI is an important driver of economic growth and prosperity. This helps to create new work places, facilitates the transfer of technology, and is an important source of capital for developing countries. Albania offers a booming market in the region with a sustainable economic structure, political, legal and economic framework and liberalized conditions for doing business. The most important sectors that have contributed to the value of foreign investments are: energy, finance, telecommunications and manufacturing industry.

The largest five banks hold about three-quarters of system assets and deposits. Subsidiaries of foreign banks (which include four of the top five banks, including from Austria, Greece, Italy, and Turkey) represent about 90 percent of total banking sector assets. Use of IMF credit from Albania in 2014 is US $\$ 150,857.00$ (IMF 2014). Albania's GDP-real growth rate is $2.6 \%$ and GDP- per capita is $\$ 11.900$ in 2015 .

During the second quarter of 2016, according to Labor Force Survey, the working age population (aged 15-64) accounts for $69.5 \%$ of the total population. Among the working age population, individuals who are economically active in the labor market (working or looking actively for a job) account for $65.8 \%$ of it. The economically inactive population accounts for $34.2 \%$ of the population aged 15-64. (INSTAT, 2016)

\section{Descriptive Data - Quality of life}

In accordance with the quality of life, child labor and street children remain the most serious problem. The main reason that affect child labor and street children, which are the most severe violations of children's rights in Albania, is related to the transformation of political system. Consequently, Albania's lack of stability in 1990's, prolonged transition in this country causing severe phenomena, conveying children's violation as one of the most negative occurrence. Even though many national and international studies and projects have been launched in order to eliminate child labor's phenomena, the problem still remains causing exploitation of children for heavy work not in accordance with their age. Since there are not certain data on street children and/or working children, the situation seems to get worse. As a result, the number of street children and child laborers might be much more than what is officially declared. Most of the children working under 18 are from rural areas. Mostly, they work in agricultural farms of their families. According to INSTAT (2016) in urban areas and rural areas work 0.3 percent and 16 percent of children respectively at age $6-14$. Only 8.9 percent of these rural areas' children dropped out of school as mostly of them attended school. Most of the child laborers, 95.6 percent, work in agriculture while only 2 percent are engaged in services. Even though percentage of child laborers is high, illiteracy in Albania seems to be low. Illiteracy in individuals derive from diverse and inter-related causes which create a series of concerns. As such, someone born into a lower economic and social class by less educated parents, hislher illiteracy is likely to be high. Interestingly, there is no correlation between child labor and illiteracy in Albania. Literacy rate for the total population in this country is $97.6 \%$ for age 15 and over that can read and write in 2015 . Among these $98.4 \%$ are male and 96.9\% are female (CIA 2017).

Eurostat gives the alarm for the increased infant mortality in Albania. According to published numbers since 2013, at 1 thousand births is 7.9 infant deaths. Compared to 2008 which was 6 deaths per one thousand births, this indicator shows an increase of 1.9. Compared with the regional countries, Albania is ranked as the penultimate place with the most negative and problematic infant mortality indicator in the Balkans. The causes affecting mostly infant mortality rates seems to be: economic level (including per capita GNP), female participation in the labor force, and female literacy rates.

\section{Business and Trade}

The value of imports in Albania was $\$ 3.402$ billion in 2015 , having declined by approximately $\$ 1$ 
billion compared to 2014. The main imported goods are machinery and equipment, foodstuffs, textiles, and chemicals. The main imports partners remain Italy $(33.4 \%)$, China (10\%), Greece (9\%), Turkey (6.7\%), and Germany (5.2\%) (CIA 2016). This country has also decreased exports, in total \$ 854.7 million in 2015. According to the data there was a decrease in exports by approximately $\$ 500$ million compared to 2014 . The main group of goods are textiles, footwear, asphalt, metals and metallic ores, crude oil, vegetables, fruits, and tobacco. The main exports partners are Italy $(42.8 \%)$, Kosovo $(9.7 \%)$, US $(7.6 \%)$, China $(6.1 \%)$, Greece $(5.3 \%)$, and Spain (4.8\%) (CIA 2017).

Intergovernmental organizations such as UN, World Bank, and World Trade Organization (WTO) play an important role in various global issues. Specifically the functions of these organizations consist primarily in the way of cooperation. Through governmental organizations, states interact and cooperate through their formal action. Many other organizations process procedures to establish rules and to resolve disputes. "The negotiators of the WTO agreements recognized that the system of rules is only as good as its implementation. They decided that the best way to ensure that the rules and other commitments are being respected is to give members themselves the information necessary to undertake collective surveillance by requiring each Member to notify specific actions or changes in policies or sometimes the absence of any action or change." (Gallagher, 2005, p.23).

The global financial system is facing the biggest challenge of the financial crisis of 2008. While in countries with rapid economic growth, such as China, India and Brazil, crisis has not had an impact on their economic growth; in Western Europe, crisis is reflected in different areas, such as in the financial, debt, budget deficits, and high unemployment. The impact of the debt crisis is felt in some Western countries such as Greece, Italy, Spain, Portugal. The global financial crisis, which started in developed countries, hit the rest of the world.

The inclusion of the Albanian economy in the global economic parameters arises at the accession of Albania to the World Trade Organization. On one hand, for Albanians, it was very important that trade rules of the game to begin with and disciplined in separate science, which includes the WTO agreements, to Cologne in the Uruguay Round. Until then, trade was spontaneous, with bags and spontaneous unconsolidated businesses, which were newly created. On the other hand, within the economic policies it did not have any determination or definition of those priority sectors, which would have to sustain in order to develop this open business and be successful in other countries.

\section{Social Impact}

One of the main social and political impact for Albania is migration which is a complex phenomenon that has affected this country for many decades. Scope, consequences and relationship of migration with trafficking in human beings transforms this issue into a serious problem. Albanian migration during 90's was one of the most dramatic events that was observed in Europe. In March 1991, a large number of Albanians entered the port of Durres and headed to Italy and ever since, illegal immigration has risen sharply. In subsequent years, particularly during 1997 with the collapse of pyramid schemes and political chaos, the flow of emigration became much more massive. Though, in recent years there has been a steady decline in illegal immigration due to the strengthening of border control, intensifying the fight against human trafficking, improving socioeconomic conditions in Albania, political stability, and order.

External migration has had a tremendous impact, both positive and negative. On one hand, remittances played an important role in alleviating unemployment and poverty throughout the difficult transition years; therefore influencing positively in the growth of material well-being. Furthermore, remittances from Albanian emigrants have contributed to the provision of valuable economic assistance not only to their families but also to the socio-economic stabilization of the country as a whole. On the other hand, migration can affect in the dispersion of families, brain drain, smuggling, and human trafficking. Whereas, many problems can find an answer only through commitment and discussion with all main international actors, including the countries of origin and the host countries. This may result to the appreciation and better gaining of benefits that migration can assure. 


\section{Social Welfare Policy}

The 1998 Albanian Constitution emphasizes concerns related to the care of the family. Children, the young, pregnant women and new mothers have the right to special protection by the state (article 54); Everyone has the right to education while mandatory education and general high school education in public schools are free of charge (article 57). It also guarantees education and qualification of children and the young, as well as unemployed persons, according to their abilities (article 59); employment under suitable conditions for all persons who are able to work (article 59); and everyone has the right to health insurance in accordance with the procedure provided by law (article 55). Social insurance includes old age retirement, disability pension, family pension, insurance against accidents, income for maternity, remuneration for childbirth, healthcare and medical care. Social insurance is financed through contributions of employers, employees, selfemployers by the state. In any case, the benefits are guaranteed by the State Budget (ISSH 2014).

\section{Analyses}

Albania has been under the Ottoman Empire from 15th century to 19th century, the time when Albanians began to eradicate from Ottoman influence. For more than four centuries, Albania has been avoided from Western civilization. Only after this period, it connected relations with the West. Relations that were about to be breaking up again when the communist regime came to power. Albania suffered under the communist regime for about fifty years, and after breaking the chains of communism, she was ready to enter into that group which promoted democratic values and respect for human rights. Since the country came out of communism, she had an eager wish to establish a democratic state. That was the main reason for Albania proclaiming to be part of democratic organizations and part of globalization as well by accepting many approaches from the West.

In the words of Robertson (1992), globalization adverts to "the compression of the world and intensification of consciousness of the world as a whole... both concrete global interdependence and consciousness of the global whole in the 20th century" (p.8). While citing another author, "globalization is identified as the intensification of worldwide social relations which links distant localities in such a way that local happenings are shaped by events occurring many miles away and vice versa." (Giddens, 1990, p.64). Hence, based on the references of different authors, I can reach in a general conclusion that everything is related to each other and world is becoming much "smaller" every passing day.

One of the risks that the process of globalization presents, consists in how we interpret it. A wrong interpretation will undoubtedly be facing us to the risk of collapse of the national states. The basic problem is the dimension of the boundaries of each country, no matter how great and powerful that country is. What makes me doubt is the fact that this process and its objective character will probably only strengthen the position of the most powerful states and will be used politically in favor of the rich. So, nation states will weaken progressively and traditional forms of democracy will be deprived of their shell. Globalization, in fact, is weakening the position of poor countries, exposing them in a harmful competition, which could be proved by looking at statistics which show that poverty has been increasing. Workplaces are not safe, as a result of a confrontational competition in the global market. For instance, if the labor force of the two countries with a different degree of development will compete for the same jobs who do you think will win? Undoubtedly workers with better preparation. And who has the best labor force preparation (specialization)? Certainly the country with the highest level of development. This would lead to the monopolization of jobs, where workers from poor countries in the international market continue to be vulnerable against international labor policies.

Despite negative aspects, globalization affects positively in many spheres including economical, financial, environmental, and cultural aspects. Globalization creates an appropriate infrastructure in which foreign investors might invest in less developed countries, creating jobs, enabling the free movement of capital (free capital flow), offering to national economies an internal dynamic, which depends not only on changes that occur in local currency, but also with international currency. Globalization seeks a common market, which will be based on the free 
exchange of goods and capital, and will provide more opportunities for the less developed countries' companies. Just competing in a global market these products are subject to its rules and compete with the products of developed countries trying to improve the quality. In a free market society, high index of consumer benefits is also indicative for the wellbeing of the country in which these customers live.

In conclusion, globalization did not have a gradual implementation in Albania, but collided furiously at a time when this country was not ready. It was not ready to manage properly the opportunities that were offered. This came as a result of lack of experience, information and funds. Consequently, the process of globalization for Albanian citizens was a sudden phenomenon, and not being able to interpret it correctly, they misunderstood it. Nevertheless, globalization brought in Albania a new way of thinking, away from conventions and ideological schemes. For Albanians, globalization represents freedom to choose, to decide, freedom to touch closely the international dream, which even today continues to accompany many of citizens.

\section{References}

CIA World Factbook. (2017). Albania. Retrieved July 17, 2017, from https://www.cia.gov/library/publications/theworld- factbook/geos/al.html

Ferrari, S., \& Durham, W.C., \& Sewell E.A. (2003). Law and religion in post-communist Europe. Leuven: Peeters Press.

Freedom House. (2016). Albania. Retrieved 2016, from, https://freedomhouse.org/report/nationstransit/2016/albania

Gallagher, P. (2005). The first 10 years of the WTO 1995-2005. Cambridge, UK: Cambridge University Press.

Giddens, A. (1990). The consequences of modernity. Cambridge, UK: Polity Press.

IMF. (2014). Albania. Retrieved March, 2014, from https://www.imf.org/external/pubs/ft/scr/2014/cr1479.pdf

INSTAT. (2016). Retrieved October 14, 2016, from http://www.instat.gov.al/en/themes/labourmarket/publications /books/2016/labour-force-survey,-q2-2016.aspx

ISSH. (2014). Retrieved 2014, from, http://www.issh.gov.al/al/

Robertson, R. (1992). Globalization: Social Theory and Global Culture. London, UK: SAGE Publications.

Trading economics. (2016). Albania. Retrieved August,2016, from http://www.tradingeconomics.com /albania/external-debt/forecast 